\title{
NEW DIRECTIONS IN AFRICAN DEVELOPMENTALISM: THE EMERGING \\ DEVELOPMENTAL STATE IN RESOURCE-RICH AFRICA
}

\author{
Sara Ghebremusse*
}

\begin{abstract}
African states are reclaiming a greater role in natural resource extraction that is generating significant scholarly interest and debate. This paper contributes to the debate by considering how these measures fit into the developmental state paradigm first used to study East Asian countries following World War II, and the "new" development state framework that currently dominates law and development scholarship. This paper argues that recent policy reforms by African states - including enhanced local participation, increased linkages between extractive industries and other sectors, and broader resource nationalist measures that seek to generate more revenue for national governments - are characteristic of the developmental state and "new" developmental state, neither have fully taken shape in resource-rich Africa as it is unclear how these new measures address "good governance" and democracy concerns.
\end{abstract}

Keywords: Developmentalism, Africa, oil, state.

doi: http://dx.doi.org/10.4314/jsdlp.v6i2.1

\section{INTRODUCTION}

There is a burgeoning scholarly debate ${ }^{1}$ surrounding recent developments in African extractive regimes, particularly as states move to reclaim greater benefits from natural resources. ${ }^{2}$ This paper intends to contribute to the debate

* Ph.D. Student, Osgoode Hall Law School at York University, Toronto, Canada.

1 Hany Besada and Philip Martin, "Mining Codes in Africa: Emergence of a "Fourth" Generation?" (2015) 28:2 Cambridge Review of International Affairs 263, 263.

2 The natural resources discussed here are limited to non-renewable natural resources (oil, gas, metals, and minerals) that are mined or removed from nature to produce raw materials. The term "resource-rich" is used to refer to any state engaged in the extraction of natural resources, regardless of the percentage of revenue the industry contributes to the national budget. This definition is intended to be broader than that used by the International Monetary 
by considering how these measures are characteristic of a "developmental state". Originally developed by Chalmers Johnson to describe the policies of Japan's Ministry of International Trade and Industry (MITI), ${ }^{3}$ the developmental state is one "that intervenes and guides the direction" of economic growth. In the context of African resource extraction, the developmental state debate has focused on whether new policies and institutions aimed at garnering greater benefits for the state are akin to not simply guiding economic growth, but more specifically if they are driving development objectives. ${ }^{5}$

The African developmental state debate has occurred in areas of study such as Political Economy, Development Studies, and African Studies; thus far, it has been largely absent from Law and Development (L\&D) scholarship. The developmental state was embraced as an analytical framework by leading L\&D scholars David Trubek, Alvaro Santos, and Diogo Coutinho, to the point where the concept was reframed as the "new" developmental state to describe recent policies of the Brazilian government. ${ }^{6}$ Orienting myself in $L \& D$ scholarship, I examine in this paper how recent regulatory reforms by African states fit into the developmental state paradigm, and the "new" developmental state framework that dominates L\&D. While several characteristics are present, this paper argues that neither the developmental state, nor the "new" developmental state, have fully taken shape in resource-rich Africa, with the possible exception of Botswana. ${ }^{7}$ However, recent policies undertaken by

Fund which restricts the description of "resource-rich" to countries where natural resource revenues contribute to at least 20 per cent of the national budget (International Monetary Fund, "Sub-Saharan Africa - Sustaining Growth amid Global Uncertainty" (World Economic and Financial Surveys, 2012) <www.imf.org/external/pubs/ft/reo/2012/afr/eng/sreo0412.pdf > accessed 23 October 2015.

3 Chalmers Johnson, MITI and the Japanese Miracle: The Growth of Industrial Policy, 1925-1975 (Stanford University Press 1982).

4 Esteban Pérez Caldentey, "The Concept and Evolution of the Developmental State" (2008) 37 International Journal of Political Economy, 27, 28.

5 Peter Meyns and Charity Musamba (eds), The Developmental State in Africa: Problems and Prospects (Institute for Development and Peace INEF-Report, 101/ 2010).

6 "Law and the New Developmental State (LANDS)" < https://law.wisc.edu/gls/ lands.html> accessed 25 November 2015.

7 Botswana's characterisation as a developmental state will not be discussed in this paper. It has previously been examined in Pamela Mbabazi and Ian Taylor (eds.), The Potentiality of Developmental States in Africa: Botswana and Uganda Compared (Dakar: CODESIRA, 2005); Peter Meyns and Charity Musamba (eds), The Developmental State in Africa: Problems and Prospects (Institute for Development and Peace INEF-Report, 101/2010); and Sara Ghebremusse, Conceptualising the Developmental State in Resource-Rich Sub-Saharan Africa" (2015) 8:2 Law and Development Review 467. 
several African states are substantial steps in the direction of an African resource-rich developmental state, with a noticeable concern - the "good governance" and democracy deficit - still needing to be addressed.

To examine these issues, I have divided this paper as follows: Section 2 discusses the history of African resource extraction to explain the varied roles of the African state in resource extraction. The developmental state and "new" developmental state are described in Section 3. Section 4 concludes the paper with an examination of the policy directives that comprise the "new directions in African developmentalism" and are contributing to the emerging resourcerich developmental state across the continent.

\section{GENERATIONS OF AFRICAN RESOURCE EXTRACTION}

Natural resource extraction in sub-Saharan Africa underwent a series of significant changes that altered state involvement in the sector since the independence era. ${ }^{8}$ The section below covers four distinct periods of African resource extraction: colonialism; the early post-colonial period; the rise of neo-liberalism; and the retreat from neo-liberalism. In the colonial era, natural resource sectors were an export enclave. Following independence, natural resource extraction was dominated by the thrust of resource nationalism. Soon after, the rise of neo-liberalism in the 1980s and 1990s pushed the African state out of the sector. In recent years, there has been a marked return to resource nationalism and a retreat from several neo-liberal policies. The generations of African extractives history from colonialism to the retreat from neo-liberalism are discussed below to provide the context for current interventions in the sectors, which are discussed further in Section 4.

\subsection{Colonialism}

Europe's colonisation and scramble for Africa was largely driven by competition among states to locate and gain control of mineral resources. ${ }^{9}$

8 Bonnie Campbell, for example, identified three distinct periods of African mining codes (Bonnie Campbell, "Factoring in Governance is Not Enough. Mining Codes in Africa, Policy Reform and Corporate Responsibility" (2003) 18:3 Minerals and Energy 2). Alternatively, Chris Roberts in "The Other Resource Curse: Extractives as Development Panacea" (2015). Cambridge Review of International Affairs, 28:2: 283 offered five distinct periods of extractive industry regulatory evolution across sub-Saharan Africa in the time since independence.

9 Economic Commission for Africa and the African Union, Minerals and Africa's Development: The International Study Group Report on Africa's Mineral Regimes (United Nations Economic Commission for Africa, 2011) 12. 
These exploitative efforts of colonial governments created dominant extractive industries across much of sub-Saharan Africa: gold production in the former Gold Coast (Ghana); copper in Northern Rhodesia (modern-day Zambia) and Belgian Congo (the Democratic Republic of Congo); and diamonds in South Africa, Sierra Leone, the Congo and the Gold Coast. ${ }^{10}$ By the early part of the twentieth century, natural resources accounted for more than 40 per cent of the exports from five colonies: the Belgian Congo; the Gold Coast; Northern Rhodesia; Southern Rhodesia (Zimbabwe); and South Africa. ${ }^{11}$ Not far behind were Angola, Sierra Leone, and South-West Africa (Namibia), where natural resources made up a significant part of these colonies' exports. ${ }^{12}$

The expansion of colonialism across Africa entrenched extractive colonial institutions, and led to the creation of enclave extractive sectors. Since natural resource extraction was an economic priority for the colonial state, necessary measures were introduced to ensure that the primacy of the sector remained intact. ${ }^{13}$ This included introducing and implementing political safeguards, legal protections, infrastructure financing, and securing much needed labour from the local population. ${ }^{14}$

Across the continent, colonial regimes reinforced the export-oriented nature of extractive industries by extinguishing local mining practices, diverting African labour to resource extraction, and directing investment to infrastructure necessary to move minerals from the interior to coastal areas for shipment outside the region. ${ }^{15}$

\subsection{Early Post-Colonial Period}

When colonial rule came to an end beginning in the late 1950s and well into the 1960s, African states inherited enclave extractive institutions that were ill equipped to respond to the immediate developmental needs of the newly independent states. ${ }^{16}$ The 2011 report prepared by the International Study Group for the United Nations Economic Commission for Africa and the African

10 ibid.

11 ibid.

12 ibid.

13 ibid 13.

14 ibid.

15 ibid.

16 Ann Seidman, Robert Seidman, Pumzo Mbana, and Hanson Hu Li, "Introduction", in Ann Seidman, Robert Seidman, Pumzo Mbana, and Hanson Hu Li (eds.), Africa's Challenge: Using Law for Good Governance and Development (Africa World Press Inc 2007) 6. 
Union lists six key features of the "externally-oriented enclave" industries inherited by African states:

i. Ownership and operation of the mines were in the hands of foreign companies;

ii. Mining operations had very weak links with the rest of the economy, because most of the minerals were exported in raw form or after only basic processing;

iii. Firms imported most of their inputs and repatriated all their profits, except what was reinvested in mining operations;

iv. Export trade figures were dominated by mineral exports, but this painted a false picture of how much the country was benefiting from minerals given the import dependence of the mines, the free repatriation of profits, technical fees charged and the incomes of expatriate employees;

v. Mining was a substantial, often the biggest, source of public revenue; and

vi. The most important skills involved in running the mines came from expatriate employees [due] to the racist division of labour under colonialism that kept Africans in low-skill, low-wage jobs. ${ }^{17}$

A key legislative measure enacted by several African states upon independence to reverse the enclave orientation of extractive industries was the introduction of national ownership of natural resources. Often this took the form of a constitutional clause, as was the case in Nigeria and Ghana. ${ }^{18}$ Along with vesting natural resource wealth in the state, African governments undertook a number of different policies aimed at further enhancing the benefits of resource extraction. These included the creation of state-owned extractive enterprises to explore mineral and oil deposits, establish production, and securing interest in already existing extractive operations. ${ }^{19}$

In the decades after independence, the efforts of African states yielded mixed results, as the potential of resource extraction was not fully realised across the continent. This sentiment was acknowledged in the Lagos Plan of Action, adopted in 1980 by the predecessor to the African Union, the Organisation of African Unity. Under the mandate of conducting a "strategic

17 UNECA/AU (n 9) 14.

18 Evaristus Oshionebo, "Fiscal Regimes for Natural Resource Extraction: Implications for Africa's Development" in Francis Botchway (ed), Natural Resource Investment and Africa's Development (Edward Elgar Publishing 2011) 200.

19 UNECA/AU (n 9) 14. 
review of Africa's development challenges and potential paths for economic growth and development", ${ }^{20}$ the Plan identified "the major problems confronting Africa in the field of natural resource development": ${ }^{21}$

Lack of information on natural resource endowment of large and unexplored areas...; lack of adequate capacity (capital, skills and technology) for the development of these resources; a considerable dependence on foreign transnational corporations for the development of a narrow range of African natural resources selected by these corporations to supply [the] raw material needs of the developed countries; the inadequate share in the value added generated by the exploitation of natural resources of member States...; non-integration of the raw materials exporting industries into the national economies of the member States thus impeding backward and forward linkages; the extremely low level of development and utilisation of those natural resources of no interest to foreign transnational corporations; and the disappointingly low general contribution of natural resources endowment to socioeconomic development. ${ }^{22}$

The acknowledgement of Africa's poor performance in resource extraction was not only clear to African states; it soon garnered the attention of international financial institutions (IFIs), most notably the World Bank, which soon enforced policies aimed at "correcting" the problems of Africa's extractive sectors. ${ }^{23}$

\subsection{The Rise of Neo-Liberalism}

At the height of African national ownership in the extractive sector, approximately 41.5 per cent of natural resource production was under state control, while another 40.5 per cent was controlled through public-private joint ventures. ${ }^{24}$ Yet, as African states entrenched themselves in their extractive

20 UNECA/AU (n 9) 5.

21 ibid.

22 ibid.

23 Bonnie Campbell, "Revisiting the Reform Process of African Mining Regimes" (2010) 30:1-2 Canadian Journal of Development Studies, 197, 200.

24 Hany Besada \& Philip Martin, "Mining Codes in Africa: Emergence of a Fourth Generation?" (The North South Institute, May 2013) <www.nsi-ins.ca/wpcontent/uploads/2013/03/Mining-Codes-in-Africa-Report-Hany.pdf > accessed 27 October 2015. 
sectors, the region received only 4 per cent of global investment in natural resource exploitation by the late $1980 \mathrm{~s} .{ }^{25}$ This inability to capitalise on natural resource wealth was attributed to the mismanagement of extractive sectors, coupled with poor governance that led to the deterioration of economic institutions in many African states. ${ }^{26}$

The response of IFIs to this failure to capitalise on natural resource wealth production was to push for de-nationalisation and to demand privatisation in the extractive sector. ${ }^{27}$ Beginning in the late 1980s, the extractive sectors in Africa underwent significant reform as both the World Bank and International Monetary Fund (IMF) pushed for the wholesale privatisation of the sectors and a redefinition of the role of the state in those industries. ${ }^{28}$ Using the mechanisms of conditionality, the IFIs were able to oversee the implementation of these reforms as African states sought financing during the 1980s debt crisis. ${ }^{29}$

The structural transformation of African extractive sectors culminated in the World Bank's 1992 report entitled, Strategy for African Mining. ${ }^{30}$ On the heels of African governments' failed attempts to get actively involved in extractive enterprises, and thus promote the sector's growth and development, the World Bank argued that African states should take a backseat and allow foreign investors to develop the potential of extractive industries in the region. ${ }^{31}$ This was deemed the best way to move the sectors forward, and provide longterm benefits (mainly through taxation) for national governments. ${ }^{32}$ The report identified key reforms: reduced or eliminated state participation in extractive enterprises; introducing a wide range of incentives to boost foreign investment; implementing more competitive tax regimes; liberalised exchange controls and exchange rate policy; and greater investment-protection measures, including stabilisation clauses in mining contracts to ensure greater security for investors. ${ }^{33}$ According to Bonnie Campbell, the report, at its core, argued, "that to adapt to modern conditions of mining, the primary objective of African countries should be to avoid state ownership and attract private investors." ${ }^{34}$

25 ibid 6.

26 ibid.

27 Accelerated Development in Sub-Saharan Africa: An Agenda for Action (The World Bank, 1981).

28 Besada and Martin, "Mining Codes in Africa" (2013) (n 24) 8.

29 ibid.

30 Campbell, "Revisiting" (n 23) 200.

31 ibid.

32 ibid 201.

33 UNECA/AU (n 9) 17.

34 Campbell, "Revisiting the Reform Process" (n 23) 201. 
In the years following the implementation of these reforms, the results were optimistically described as "mixed at best". ${ }^{35}$ Although the reforms did promote levels of foreign investment by creating a more favourable investment environment, they failed to achieve the promised advancements in socioeconomic development goals. ${ }^{36}$ A 2007 "Policy Big Table" - comprising officials from African governments, the African Union, the African Development Bank, the United Nations Economic Commission for Africa, and members of international organisations - concluded that "African efforts to attract [foreign investment] to their natural resources sector, which led to the formulation of overly generous investment laws and regulations", ${ }^{37}$ failed to generate benefits from the exploitation of natural resources.

\subsection{The Retreat from Neo-Liberalism}

The failure of neo-liberal policies to advance socio-economic development catalysed African states to take broader action in their extractive sectors. ${ }^{38}$ Motivated by the importance of natural resource wealth to revenue generation (particularly for the African states fiscally dependent on revenues derived from resource extraction), ${ }^{39}$ African governments are creating greater policy space and inserting themselves more in their extractive sectors. ${ }^{40}$

Recognising the importance of resource extraction to the socio-economic development, African states gathered under the auspices of the African Union and concluded the Africa Mining Vision (AMV) in 2009..$^{41}$ The Vision intends to promote "transparent, equitable and optimal exploitation of mineral resources to underpin broad-based sustainable growth and socio-economic development." ${ }^{42}$ In his article discussing the AMV, Antonio Pedro (the Director of UNECA's Sub-regional Office for Eastern Africa) described the following four "principal opportunities" for the implementation of the AMV:

35 UNECA/AU (n 9) 17.

36 ibid.

37 ibid.

38 Besada and Martin, "Mining Codes in Africa" (2013) (n 24) 4.

$39 \operatorname{IMF}$ (n 2).

40 Besada and Martin, "Mining Codes in Africa" (2013) (n 24) 4.

41 UNECA/AU (n 9) 19.

42 Antonio Pedro, "The Africa Mining Vision: Towards Shared Benefits and Economic Transformation" (2012) 1:5 Great Insights Magazine < http://ecdpm.org/greatinsights/extractive-sector-for-development/the-africa-mining-vision-towardsshared-benefits-and-economic-transformation/> accessed 3 November 2015. 
1. To optimise the capture, management, sharing and use of resource rents to improve physical, social and human capital and infrastructure...

2. The collateral use of the high-rent resource infrastructure to open up other resource potential in areas such as agriculture, forestry and tourism, and to provide access to zones of economic potential with lower returns, but that cannot afford their own infrastructure.

3. To promote downstream value addition, through the use of the locational advantage of producing crude resources, with a view to establishing resource-processing industries...

4. To promote upstream value-addition through the use of relatively large resources sector market to develop the resource supply and inputs sector... ${ }^{43}$

Seen as an attempt to correct the failed neo-liberal policies of the IFIs, the AMV actively rejects African states merely acting as passive regulators of extractive industries and encourages a turn towards the "developmental state". ${ }^{4}$

\section{THE DEVELOPMENTAL STATE ${ }^{45}$}

At its core, the "developmental state" is committed to economic development. It is generally characterised as "a state that intervenes and guides the direction"46 of economic growth. Chalmers Johnson's 1982 study of Japan and its Ministry of International Trade and Industry (MITI) was the first to profile the characteristics of this state model. In his landmark study, MITI and the Japanese Miracle, ${ }^{47}$ Johnson identified four key components of the developmental state: a small, efficient bureaucracy; a political environment that allows the bureaucracy to operate independently and free of intrusive interests; state intervention in the economy; and pilot institutions, such as the

43 ibid 2. Fully discussing the AMV and the commitments it outlines is not the purpose of this section. Further details about the AMV are available in Besada and Martin (n 1), and Pedro (n 43).

44 ibid.

45 Section 3 first appeared in Sara Ghebremusse, "Conceptualising the Developmental State in Resource-Rich Sub-Saharan Africa" (2015) 8:2 Law and Development Review 467. It is copied here with permission of the Editor. 46 Caldentey (n 4) 28.

47 Johnson (n 3). 
MITI. ${ }^{48}$ Although state intervention was common among both industrialised and developing economies in the decades following World War II, the developmental state offered a way to characterise governments that went beyond intervention alone and used it as a tool to advance economic growth.

After dominating economic policymaking in the mid-twentieth century, active state intervention faced opposition as neo-liberal economic policies gained popularity in the 1980s. The rise of neo-liberalism coincided with the decline of the developmental state, as neo-liberals argued it was not equipped to handle the economic crises that arose in the late 1970s and early 1980s. As a result, the role of the state in development receded in the face of neo-liberal policies that favoured deregulation, free trade, and privatisation. Today, after years of what many scholars agree was a failure of neo-liberal policies to promote development ${ }^{49}$ several developing countries are channelling the principles of the developmental state model proposed by Johnson. According to Karl Botchway and Jamee Moudud, the mediocre record of neo-liberalism has revived support for state intervention and refocused attention on the role of the state in development. ${ }^{50}$ David Trubek describes this modern developmental state as the "new developmental state". ${ }^{51}$

\subsection{The "New Developmental State" and the Evolution of Law and the Developmental State}

Alongside the evolution of developmental state theory in political science, economics, and international political economy was its critical alignment with L\&D scholarship. As a field of study, L\&D consistently shifted due to its intersections with "law, economics, and the practices of states and development agencies". ${ }^{52}$ The first major iteration of L\&D scholarship emerged in the

48 Pamela Mbabazi and Ian Taylor, "Botswana and Uganda as Developmental States(?)" in Pamela Mbabazi and Ian Taylor (eds), The Potentiality of 'Developmental States' in Africa: Botswana and Uganda Compared (CODESIRA 2005) 4.

49 See for example Joseph Stiglitz, Globalisation and Its Discontents (WW Norton \& Co. 2002) and Dani Rodrik, 'After Neo-liberalism, What?' (Harvard University, August 2002), <www.bndespar.com.br/SiteBNDES/export/sites/default/ bndes_pt/Galerias/Arquivos/conhecimento/seminario/novosrumos_Dani.pdf > accessed 14 December 2014.

50 Karl Botchway and Jamee Moudud, "The Search for a New Developmental State" (2008) 37:3 International Journal of Political Economy 5, 6.

51 David M Trubek, "Law, State, and the New Developmentalism: An Introduction" in David M Trubek, Helena Alvair Garcia, Diogo R Coutinho, and Alvaro Santos (eds), Law and the New Developmental State: The Brazilian Experience in Latin American Context (Cambridge University Press 2013) 3.

52 ibid. 
1960s among American legal scholars as "the law and development movement." 53 Influenced by the modernisation theory of WW Rostow, which contended that development occurred in a period of successive phases of economic growth, these scholars advocated that the adoption of Western legal traditions could foster Third World modernisation. ${ }^{54}$ Consequently, this movement supported a "top-down" approach that consisted of reforming the legal profession to train lawyers to use law as a means of achieving the developmental goals of the state. ${ }^{55}$

L\&D's encounter with the developmental state historically covers two distinct time periods. The first can be described as "law of the developmental state". ${ }^{56}$ During this period, law was used as a tool of the developmental state, specifically directed to making state intervention more effective. This approach was used mostly in the 1960s and early 1970s, when development economists favoured the state guiding industrial growth over the private sector. ${ }^{57}$ Private sector actors were considered less equipped to manage the demands of industrial expansion; thus states were regarded as better suited to carrying out development. ${ }^{58}$ The second period emerged in the 1980s after doubts were raised about the developmental state's effectiveness.

With the shift towards more neo-liberal economic policies advanced by IFIs, "law in the neo-liberal market"59 became the second encounter between law and the developmental state. Law's role in the economy morphed during this period from a tool to advance development goals, to a shield used to protect the market against unwanted state intervention. ${ }^{60}$ The role of the state was limited to using law as a means to protect investor expectations and facilitate private business transactions. ${ }^{61}$ Since the late 1990s, however, IFIs have rejected the neo-liberal "night watchman" concept of the state and

53 Kevin Davis and Michael Trebilcock, "The Relationship Between Law and Development: Optimists versus Skeptics" (2008) 56 American Journal of Comparative Law 895, 900.

54 ibid 901.

55 ibid.

56 Trubek, "New Developmentalism" (n 51) 5.

57 ibid.

58 ibid.

59 ibid.

60 ibid.

61 ibid. 
accepted that various market distortions and failures may require intervention and direct corrective action. ${ }^{62}$

Today, there is no prevailing theory that is shaping the relationship between law and the developmental state. David Trubek suggests that "the consensus on which the neo-liberal model was built is crumbling," ${ }^{63}$ while new conceptions are emerging from state practices and development scholarship. The absence of a theoretical consensus on the role of law in the developmental state has led to what Trubek calls the "new developmental state." ${ }^{64}$ In the midst of the current theoretical vacuum, different ideas about the developmental state are emerging that rely on "different models of development and different roles for law". ${ }^{65}$

An overarching feature of this new developmental state is the revised relationship between the state and the private sector. No longer is the state acting as the sole guiding hand of the economy; neither is the private sector seeking to act unilaterally with little involvement from the state. Instead, new developmentalism acknowledges that optimal development goals will be realised if the state and the private sector collaborate. New developmentalists posit that this can include public-private partnerships, and other joint efforts that originate from state promotion of industrial innovation and competitiveness. ${ }^{66}$ Policies that may characterise this new developmental state include:

- $\quad$ Primary reliance on the private sector as investor rather than direct state ownership [with natural resource sectors being a possible exception];

- Acceptance of a major role for the state in steering investment, coordinating projects and providing information;

- $\quad$ Promotion of productive (rather than speculative) foreign direct investments; [and]

- Emphasis on making private firms competitive rather than on shielding them from competition. ${ }^{67}$

62 Kerry Rittich, "The Future of Law and Development: Second-Generation Reforms and the Incorporation of the Social" in David Trubek and Alvaro Santos (eds), The New Law and Economic Development: A Critical Appraisal (Cambridge University Press 2006), 212.

63 Trubek, "New Developmentalism" (n 51) 5.

64 ibid.

65 ibid.

66 ibid 9.

67 David M Trubek, "Developmental States and the Legal Order: Towards a New Political Economy of Development and Law" (2008) University of Wisconsin Legal Studies Research Paper No. 1075, 11. 
Whether the "new developmental state" exists in Africa has not been thoroughly explored in either the developmental state literature or in L\&D scholarship. Following the historical overview of the developmental state in Africa in Section 3.2, I will examine how recent reforms in African extractive sectors mirror the "new developmental state" (as characterised by Trubek) in Section 4.

\subsection{An Overview of the Developmental State in Africa}

In most instances, the scholarship concerning African developmental states centres on the question of whether the model is even possible. Referred to as "impossibility theorems", some Africanist developmental state scholarship attempts to debunk these theses. ${ }^{68}$ They contend the arguments are not based on the reality of Africa's historical, political, or economic climate: the developmental state existed in many parts of Africa, and still can today. This section discusses the history of the African state in development, and examines the replicability and rationale for the developmental state in Africa.

\subsection{History of the African State in Development}

Like Japan, African governments became dominant players in socio-economic development after the end of a tumultuous period in history. The end of colonialism and new-found independence thrusted African governments into the centre of their states' development trajectories. Post-colonial leaders of Africa's newly independent states inherited the task of pursuing social and economic development from colonial predecessors that had practically ignored the task entirely. As heads of nationalist parties that dominated the postcolonial one-party state system, these leaders and their parties quickly became synonymous with the state as agents of development. ${ }^{69}$ Kwame Nkrumah in Ghana, Tanzania's Julius Nyerere, and Kenneth Kuanda in Zambia are a few examples. ${ }^{70}$ At independence these leaders were faced with a weak, almost non-existent private sector, which led many states to assume the role of the

68 Thandika Mkandawire, "Thinking about Developmental States in Africa" (2001) 25 Cambridge Journal of Economics 292, 309-310.

69 Karl Botchway and Jamee Moudud, "Neo-liberalism and the Developmental State: Consideration for the New Partnership for Africas Development" in Benjamin F Bobo and Hermann Sintim-Aboagye (eds), Neo-liberalism, Interventionism and the Developmental State: Implementing the New Partnership for Africa's Development (Africa World Press Inc 2012) 16.

70 ibid. 
main economic actor. This responsibility extended from constructing social and economic infrastructure, to owning and managing productive industries. ${ }^{71}$

For some scholars, the centrality of development to this group of postcolonial leaders is sufficient to describe these states as developmentalist. ${ }^{72}$ For others, these leaders' records raise serious doubts about early post-colonial developmentalism in Africa. ${ }^{73}$ Although development was a priority for several leaders, some scholars argue that consolidating power was another objective that detracted from developmentalism. Claude Ake, for example, contends that state intervention was not used to promote development, but rather "to facilitate the appropriation of wealth by means of state power."74 The early development failures across sub-Saharan Africa - particularly in Nigeria, Liberia, Sierra Leone, and Zaire - are used to support this view. ${ }^{75}$

Despite some of these failures of early African leaders, development remained a central priority throughout the remainder of their political careers and those of their successors. Although the "state-development nexus"76 altered as growth in African economies began to decline during the period of economic hardship in the 1970s, African states remained active participants in development as neo-liberalism gained prominence in the $1980 \mathrm{~s} .{ }^{77}$ When the neoliberal-inspired structural adjustment programmes failed to meet expectations, even IFIs accepted a role for the state in the development process. ${ }^{78}$ However, state involvement was predicated on the notion of "good governance" advanced by those same IFIs. ${ }^{79}$

71 Meyns and Musamba (n 5) 28.

72 Mkandawire, "Thinking" (n 68) 291.

73 Meyns and Musamba (n 5) 29.

74 Claude Ake, Democracy and Development in Africa (Brookings Institution 1996) 6.

75 ibid; Meyns and Musamba (n 5) 29.

76 Howard Stein, "Rethinking African Development" in Ha-Joon Chang (ed), Rethinking Development Economics (Anthem Press 2003) 159.

77 Francis B Nyamnjoh and Ignasio M Jimu, "Success or Failure of Developmental States in Africa: Exploration of the Development Experiences in a Global Context" in Pamela Mbabazi and Ian Taylor (eds), The Potentiality of Developmental States in Africa: Botswana and Uganda Compared (CODESIRA 2005) 27.

78 Mkandawire, "Thinking” (n 68) 292.

79 ibid. 


\subsection{Replicability and Rationale of the Developmental State in Africa}

The mixed history of the African state in development raised doubts about the success of the East Asian developmental state model in the post-adjustment era. Some scholars argued that the developmental state was economically and culturally unique to East Asia, and beyond the political and institutional capacity of African governments. ${ }^{80}$ Mkandawire categorises these "impossibility theses" as: lack of ideology; dependence syndrome; lack of autonomy; neopatrimonialism and rent seeking; the lack of technical and analytical capacity; and a poor record of performance. ${ }^{81}$

Mkandawire dismisses these arguments by arguing that they are not based on African historical experiences, nor on the development trajectories of successful developmental states. ${ }^{82}$ According to Mkandawire, the climate exists in Africa for the developmental state. He contends that developmentalism has historically been a priority for African leaders, thus refuting the lack of ideology argument. He also dismisses the neo-patrimonial and rent seeking arguments based on historical evidence. Neo-patrimonialsim and rent seeking are automatically equated with corruption and patron-clientelism, without determining whether such behaviour is advancing developmental goals or not. ${ }^{83}$ Mkandawire notes that both neo-patrimonial and rent seeking behaviour can positively impact growth through the redistribution of resources. In support of his argument, Mkandawire asserts corruption in high-performing East Asian developmental states was common, and did not deter industrialisation. ${ }^{84}$

Despite the replicability debate, there is greater consensus in developmental state literature regarding the role it can play in promoting development in modern Africa. During the colonial period, African resources were misallocated as colonial institutions were extractive and restricted production. Many of these colonial institutions remained intact after independence was secured. ${ }^{85}$ In addition to inheriting extractive colonial institutions, newly independent African states were left without a civil service,

80 Botchway and Moudud, "Neo-liberalism" (n 69) 24.

81 Mkandawire, "Thinking" (n 68) 294-298; Botchway and Moudud, "Neoliberalism" (n 69) 25.

82 Mkandawire, "Thinking" (n 68) 309.

83 Botchway and Moudud, "Neo-liberalism" (n 69) 25.

84 Mkandawire, "Thinking" (n 68) 299.

85 Seidman (n 16) 4, 6. 
a strong-centralised taxation system, or vital infrastructure. ${ }^{86}$ The state structure at that time was ill equipped to meet the development objectives of newly independent states. ${ }^{87}$ Over fifty years of independence have not changed the state structures in many African states that struggled to build state institutions amidst war, civil strife, and the lack of adequate resources.

Across the region today the state structure remains poor. Howard Stein describes this as a "developmental crisis" - African economies are incapable of generating the conditions necessary for sustained levels of growth and improvements in the standard of living. ${ }^{88}$ Poverty, unemployment, and inequality rates remain high while several states are mired in conflict, disease, famine, and low levels of agricultural and industrial production, despite the abundant natural resources and human capacity that a developmental state can harness to promote meaningful economic development. ${ }^{89}$

\section{NEW DIRECTIONS IN AFRICAN DEVELOPMENTALISM}

The varied involvement of African states in natural resource extraction has led many commentators to speculate on how state involvement should be framed. My purpose in this section is to consider how recent legal reforms in the extractive sector fit into the developmental state frame- work. More significantly, these reforms are contributing to an emerging developmental state that mirrors the "new developmental state" and is unique to resourcerich states, as governments in these nations are "intervening more forcefully in the sector". ${ }^{90}$ Of the forms of state intervention discussed below, two key themes link these actions to the new developmental state framework. First, states are intervening to accrue more revenue; the recent increase in commodity prices gave resource-rich states the opportunity to revise fiscal regimes and earn more revenue from natural resource extraction. ${ }^{91}$ Generating more revenue can assist African states in directly achieving socio-economic development goals, which is a central tenet of the developmental state. Second,

86 ibid.

87 ibid.

88 Stein (n 76) 153.

89 Nyamnjoh and Jimu (n 77) 18.

90 Martin Kwaku Ayisi, "The Review of Mining Laws and the Renegotiation of Mining Agreements in Africa: Recent Developments from Ghana" (2015) 16 Journal of World Investment \& Trade, 467, 473.

91 ibid 474. 
these recent legal reforms support continued state involvement in extractive industries through revised relationships with the private sector, thereby enhancing the opportunity for long-term benefits that can contribute to the growth, and evolution, of extractive industries.

To conclude the examination of the recent legal reforms in African extractive sector, this section discusses the "good governance" and democratic deficit critique that may limit the characterisation of a number of resourcerich African states as developmental states.

\subsection{Enhancing Local Participation}

To maximise the benefits of foreign investment in extractive industries, many African states introduced "indigenisation and local equity schemes" ${ }^{92}$ Defined broadly as "local content requirements" (LCRs), these measures typically demand that "a certain percentage of intermediate goods used in the production processes ... be sourced from domestic manufacturers. ${ }^{193}$ LCRs can take many forms, including:

... mandating foreign firms to give preferences to local suppliers in the procurement of goods and services, preferences to local labour in matters of employment and preferences to (or mandatory minimum percentages in) the use of local raw materials in production. They may also take the form of "price preferences" to domestic firms that participate in government procurement bids, "import licensing procedures designed to discourage foreign suppliers, and discretionary guidelines that both encourage domestic firms and discourage foreign firms." 94

There are a number of reasons for resource-rich countries to adopt LCRs. Chilenye Nwapi contends that:

92 ibid 480.

93 Sherry M. Stephenson, "Addressing Local Content Requirements: Current Challenges and Future Opportunities" (2013) 7:3 BIORES, available at $<$ www.ictsd.org/bridges-news/biores/news/addressing-local-contentrequirements-current-challenges-and-future $>$ accessed 15 November 2015.

94 Cathleen Cimino, Gary Clyde Hufbauer and Jeffrey J. Schott, A Proposed Code to Discipline Local Content Requirements (Peterson Institute for International Economics Policy Brief No PB14-6, February 2014) 1, <www.iie.com/ publications/pb/pb14-6.pdf> quoted in Chilenye Nwapi, "Defining the 'Local' in Local Content Requirements in the Oil and Gas and Mining Sectors in Developing Countries" (2015) 8:1 Law and Development Review, 187, 191. 
They are undertaken to reduce inequalities faced by domestic companies in relation to foreign companies, increase the participation of the national industry in specific sectors of economic activity, improve national technological development, create job opportunities for nationals to improve their personal income, support economic diversification, promote intersectoral linkages and reduce overdependence on one sector by enhancing the valuecreating capacity of a particular sector, and to enable domestic companies to compete regionally and internationally. ${ }^{95}$

In resource-rich Africa, specific LCRs undertaken range from local employment quotas to the preferential treatment of companies with higher levels of local procurement. The following examples highlight some of these local participation measures:

- Burkina Faso introduced detailed obligations in its mining sector outlining that preference should be given to local businesses in the procurement of goods and services; local employees should be hired to fill senior executive positions, which include a training programme to ensure the progressive replacement of foreign staff in senior positions; and that local labour be employed in low-skilled jobs. ${ }^{96}$

- $\quad$ Guinea's 2011 Mining Code introduced the requirement that feasibility studies submitted for mining concessions and permits "must include a plan of support for building or strengthening the capacity of local small and medium enterprises, or enterprises belonging to, or controlled by Guineans for supplying goods and services for their activities and a plan of promotion of employment of Guineans according to the quotas established by the code." 97

- $\quad$ Similarly, Angola and Nigeria implemented local content strategies in their oil and gas sectors that emphasise indigenous labour, and

95 Chilenye Nwapi, "Defining the 'Local' in Local Content Requirements in the Oil and Gas and Mining Sectors in Developing Countries" (2015) 8:1 Law and Development Review, 187, 191.

96 Stéphanie Brabant, "Current Trends in Mining Law and Regulation in West Africa" (MineAfrica 4th Annual Focus on West Africa Seminar, London, October 2014) 41.

97 Ana Elizabeth Bastida, "From Extractive to Transformative Industries: Paths for Linkages and Diversification for Resource-Driven Development" (2014) 27 (23) Mineral Economics. 73, 77. 
preferential treatment of local companies for the procurement of goods and services. ${ }^{98}$

- In Botswana, the government implemented local participation strategies that aim to sustain greater linkages to downstream diamond industries, including cutting and polishing, and jewellery manufacturing. The creation of the Botswana Diamond Hub, and securing the sales agreement with De Beers that moved the company's rough diamond sales division to Gaborone, are two measures aimed at increasing local participation. ${ }^{99}$

- Ghana's Minerals and Mining Act (2006) promotes local participation by reserving small-scale mining for Ghanaian citizens; requiring gold mining companies to give preferential treatment to locally made products, and the recruitment of local labour, which includes the creation of a mandatory training programme designed to ensure the progressive replacement of foreign staff by local personnel. ${ }^{100}$

\subsection{Developing Linkages}

The Africa Mining Vision identified harnessing linkages as a key area of improvement for extractive sectors. ${ }^{101}$ Since mineral endowments are finite and prone to price volatility, integrating the industry into other areas of the national economy can provide long-term benefits to resource-rich countries. ${ }^{102}$ Integration can occur by developing a number of relationships between the extractive sector and other industrial sectors. Possible "linkages" include upstream linkages, downstream linkages, and side stream linkages. ${ }^{103}$

Broadly speaking, upstream (or backward) linkages are the relationships between an industry and its suppliers. In the extractive sector, upstream linkages arise early in the production process "as deposits are identified, assayed and quantified; finance secured; legal and permitting issues addressed; plans for development and earthworks commissioned; and labour, raw materials

98 Jesse Ovadia, "Local Content and the Emergence of the Petro-Developmental State in the Gulf of Guinea" (PhD thesis, York University 2013).

99 Bastida (n 107) 79.

100 Robin Bloch and George Owusu, "Linkages in Ghana's Gold Mining Industry: Challenging the Enclave Thesis" (2012) 37 Resources Policy 434, 437.

101 UNECA/AU (n 9) 101.

102 ibid.

103 ibid 103, 104, 106. 
equipment and utilities sourced." ${ }^{104}$ Alternatively, downstream linkages (also referred to as forward linkages) connect extracted resources to value-added production processes: smelting or refining, semi-fabrication, or final product manufacturing. ${ }^{105}$ Side stream linkages are created when the extractives industry helps build other industries, such as "financial services, power, logistics, communications, skills and technology development". ${ }^{106}$

Many African states reversed their positions on having investors support linkage development from the 1980s when it was thought this requirement could deter foreign investment. ${ }^{107}$ Today, supplementary investments that support linkage creation are widespread. Many are infrastructure focused, and require certain investments in transportation networks and power grids. ${ }^{108}$ Such measures have been undertaken in Angola, the Democratic Republic of the Congo, Gabon, Liberia, Mozambique, Tanzania, and Zambia. ${ }^{109}$

\subsection{Broader "Resource Nationalism" "110}

In addition to state efforts to increase local participation and strengthen sectoral linkages, African states are inserting themselves in the extractives industry by increasing state interests in extractive projects, reviewing and renegotiating contracts with foreign investors, and reforming fiscal regimes to ensure a greater share of resource revenue.

After the neo-liberal structural adjustment in the 1980s and 1990s did not yield the success African states were expecting, many are now asserting greater roles either directly or indirectly through state-owned enterprises. Through state participation, African states can directly share in the financial rewards available from extractive sectors, rather than being a passive collector of tax revenue. ${ }^{111}$ State participation offers a number of benefits to African

104 ibid 103.

105 Bastida (n 97) 74; UNECA/AU (n 9) 104.

106 Bastida (n 97) 74; UNECA/AU (n 9) 106.

107 UNECA/AU (n 9) 107.

108 Besada and Martin, "Mining Codes in Africa" (2015) (n 1) 276.

109 ibid.

110 The characterisation of tightening regulation in the extractives industry as "resource nationalism" is problematic for some scholars. Martin Kwaku Ayisi provides a brief overview of this debate in his article, "The Review of Mining Laws and the Renegotiation of Mining Agreements in Africa: Recent Developments from Ghana" (n 100), and concludes that the label "can only obstruct a better understanding of why and how contemporary governments are intervening more forcefully in the sector" (473).

111 MA Ayoade, "Nigerian Petroleum Profits Tax and Financial Incentives: 50-Year Requiem?” (2008-2010) 24 UGLJ 171, 173. 
oil-producers; of particular relevance to the fiscal regime is the ability to potentially increase government revenues beyond what the regime normally provides. ${ }^{112}$ There are various versions of state participation, including equity participation (where government acquires a stake in production), service agreements and production sharing agreements. ${ }^{113}$

Several African states introduced recent changes to their participatory regimes that increased the level of equity participation, installed minimum levels of equity participation, and stipulated that additional levels of participation are at the discretion of the state. ${ }^{114}$ Some mining examples include:

- $\quad$ Côte d'Ivoire, which requires 10 per cent state participation for zero dollars, and up to an additional 15 per cent (unless the state is involved in exploration); ${ }^{115}$

- $\quad$ Guinea, where the state is empowered to acquire interest in a project "on a fully paid basis up to a maximum shareholding of 35 per cent," 116 which is in addition to the 15 per cent equity participation available for free upon the issuance of a mining licence for bauxite, iron ore, uranium, gold, and diamond deposits; ${ }^{117}$

- Mali and Mauritania, which require 10 per cent free participation, and an additional negotiated 10 per cent participation; ${ }^{118}$ and

- Togo, where 10 per cent free participation is mandatory, and an additional 20 per cent can be negotiated. ${ }^{119}$

A number of contract reviews and renegotiations were aimed at amending stabilisation clauses. Stabilisation clauses are either contractual or statutory obligations that aim to "freeze" the law of the host country to the date the

112 World Bank, Taxation and State Participation in Nigeria's Oil and Gas Sector (August 2004) 41 <http://documents.worldbank.org/curated/en/2004/08/ $5539607 /$ taxation-state-participation-nigerias-oil-gas-sector $>$ accessed 26 October 2015.

113 Evaristus Oshionebo, "Fiscal Regimes for Natural Resource Extraction: Implications for Africa's Development" in Francis Botchway (ed), Natural Resource Investment and Africa's Development (Edward Elgar Publishing, 2011) 200.

114 Brabant (n 96) 31.

115 ibid.

116 Ayisi (n 90) 480.

117 ibid.

118 Brabant (n 96) 32.

119 ibid. 
national government enters into an agreement with an extractives company. ${ }^{120}$ The effect is to insulate the corporation from future changes to the host country's laws, which could potentially harm its investment. The reviews that took place in Burkina Faso, Côte d'Ivoire, Guinea, and Ghana are examples of amendments made to shorten the length of the clause.

Lastly, several states increased royalty rates, and other fiscal measures such as corporate tax rates, to ensure higher levels of resource revenue. ${ }^{121}$ Examples include Burkina Faso, Côte d'Ivoire, Ghana, and Guinea. ${ }^{122}$

\subsection{Good Governance and Democracy Concerns}

The contact between natural resources and African governments has generally been characterised as problematic. Critics of the handling of African resource wealth used the "resource curse" thesis to explain Africa's mismanagement of the sector. ${ }^{123}$ The thesis contends that natural resource endowment is more of a curse than a blessing to resource abundant countries, in contrast to resource poor states. ${ }^{124}$ Although the thesis was originally developed to explain slow economic growth, it evolved to capture two other phenomena: weak political institutions, and a higher prevalence of civil conflicts. ${ }^{125}$ Both were linked to the rent-seeking and corrupt behaviour of political elites. ${ }^{126}$ Despite resource wealth credited as the cause of political violence in places like the Democratic Republic of the Congo and Sierra Leone,${ }^{127}$ there is no consensus about the correlation between the two. ${ }^{128}$

The detrimental impact of natural resource wealth on African political processes was of particular concern to IFIs. In particular, the "governance matters" mantra that began in the late 1980s and continued into the 1990 s

120 Evaristus Oshionebo, "Stabilisation Clauses in Natural Resource Extraction Contracts: Legal, Economic, and Social Implications for Developing Countries" (2010) 10 Asper Rev. of Int'l Bus. and Trade Law 1, 1.

121 Stephenson (n 103) 35.

122 ibid; Ayisi (n 100) 494.

123 Besada and Martin, "Mining Codes in Africa" (2013) (n 25) 6.

124 Richard Auty, Sustaining Development in Mineral Economies: The Resource Curse Thesis (Routledge 1993).

125 Patrícia Galvão Ferreira, Breaking the Weak Governance Curse: Global Regulation and Governance Reform in Resource-Rich Developing Countries (SJD Thesis, University of Toronto Faculty of Law, 2012) 287.

126 Philip Martin, “A Closer Look at Botswana's Development: The Role of Institutions" (2008) 9 Paterson Review, 35, 38.

127 ibid 36-37.

128 Ferreria (n 125) 29. 
ushered in a new era of focus on African institutions. Since the emergence of the "good governance" agenda, it became easier to contend that "the lack of democratic accountability and the presence of patron-client politics, extensive corruption, and a weak rule of law"129 contributed to the poor management of natural resources in Africa.

The contemporary intervention of African states in extractive industries is raising concerns for those who subscribe to the "governance matters" mantra. ${ }^{130}$ Any absence or lack of democratic institutions, such as multi-party elections, the rule of law, transparency, accountability, and presidential term limits tends to overshadow the potential success of African state intervention in extractive industries. ${ }^{131}$ Despite previous recommendations made in reports issued by IFI (including the World Bank's Extractive Industries Review) to limit state involvement, it is unlikely those past concerns will limit state action today. Instead, it begs the question of whether contemporary forms of intervention, as manifested in the emerging resource developmental state framework, can respond to good governance concerns.

\section{CONCLUSION}

As African states expressed in the Africa Mining Vision, natural resource extraction presents a unique opportunity to advance socio-economic development by "integrating the sector more coherently and firmly into the continent's economy and society." 132 Recent policies introduced by African governments are indicative of this emerging resource-rich developmental state - governments are seeking ways to garner greater benefits from extractive industries through direct state intervention and revised relationships with the private sector by enhancing local participation, developing linkages between the extractive sector and the broader economy, and implementing broader resource nationalist reforms that include contract reviews, revised fiscal regimes to ensure a greater share of resource revenue, and increased levels of equity participation in extractive projects.

129 Mushtaq H Khan, "Governance and Growth Challenges in Africa" in Akbar Noman, Kwesi Botchwey, Howard Stein and Joseph E. Stiglitz (eds), Good Growth and Governance in Africa: Rethinking Development Strategies (Oxford: Oxford University Press, 2011) 115.

130 Botchway and Moudud, "The Search" (n 50) 16.

131 ibid 35.

132 UNECA/AU (n 9) 9. 
While several African governments are making these strides towards a resource-rich developmental state, the concept is yet to fully form across much of the region as it is unclear how this emerging state model can achieve the "transparent, equitable and optimal exploitation of mineral resources"133 that avoids the lack of accountability, presence of patron-client politics, extensive corruption, and weak rule of law so characteristic of African resource extraction. ${ }^{134}$ As Thandika Mkandawire warns,

we should avoid an idealised view of the developmental state as omnipotent and omniscient... In many ways, the discovery of the developmental state has tended to produce its own mystification of a non-corrupt, dedicated, omniscient bureaucracy that selflessly and patriotically manages economic transformation of its society. ${ }^{135}$

Thus, the emerging developmental state alone is likely not the panacea for reversing the paradox of plenty that contributes to Africa's developmental crises. It is likely a combination of governance and development-oriented legal and fiscal frameworks that can advance the "broad-based sustainable growth and socio-economic development" envisaged by the AMV ${ }^{136}$ As Bonnie Campbell has noted, "while the quality of national governance is undoubtedly a key ingredient, no amount of ... governance is sufficient if not accompanied by legal and fiscal frameworks designed to meet development objectives..."137

133 ibid 5.

134 Khan (n 129).

125 Thandika Mkandawire, "From Maladjusted States to Democratic Developmental States in Africa" in Constructing a Democratic Developmental State in South Africa (Cape Town: Human Science Research Council, 2010) 78.

136 UNECA/AU (n 9) 5.

137 Campbell, "Factoring" (n 8) 2. 